\title{
The Afrikaans Orthographic Rules as Guide for Other South African Languages*
}

\author{
Mariëtta Alberts, Research Unit for Languages and Literature in SA Context, \\ Northwest University, Potchefstroom Campus, Potchefstroom, \\ South Africa (malberts@lantic.net)
}

\begin{abstract}
The spelling and orthographic rules of a language are very important for compilers of general and technical dictionaries. When compiling a dictionary, the lexicographers and terminographers should adhere to these rules. The word-forming principles of a language form part of these rules, and new terms can only be coined in a given language if the spelling and orthographic rules of the language are followed.

In this article work on the rules of Afrikaans spelling and orthography, by and large, is reported. It is hoped that some of the lessons learned in the process could serve as guidelines for parallel processes of the standardisation of the spelling and orthographies of the other South African languages.

With the establishment of the National Language Body for Afrikaans (NLBA) of the Pan South African Language Board (PanSALB), it was decided that the members of the Taalkommissie (Language Commission) of the Suid-Afrikaanse Akademie vir Wetenskap en Kuns (SAAWK) (South African Academy for Science and the Arts) would become members of the NLBA. These members then became the Technical Committee for Standardisation (TC Standardisation). Since its establishment, the members of the Taalkommissie cum TC for Standardisation (Commission) continued with their work on the standardisation of the spelling and orthographic rules for Afrikaans. Along with work on spelling and orthography, the long-term objectives set by the Commission are, inter alia, the conversion and adaptation of the Afrikaanse Woordelys en Spelreells (AWS) to an electronic format to be made available in an electronic version (e-book) and online, as well as a standard grammar for Afrikaans to be compiled for international access on the Internet.

The AWS is a resource compiled by the Commission to assist users of Afrikaans in writing the standard variety of the language. The AWS explains the ground rules of the Afrikaans spelling and orthographic conventions. The basic rules are provided in simplified language.

No language is static, and there are always language changes to be taken into account. The vocabulary and pronunciation of a dynamic language could change over a period of time. These changes should be reflected in the spelling and orthographic system of the language.

The article addresses issues such as the front matter of the AWS, spelling and orthographic principles and rules, and the back matter (i.e. a list of abbreviations, a list of international place

* This article is based on a paper "The Work on the Afrikaans Spelling and Orthography Rules as a Model for the Other Official Languages", presented by the author at the Eighteenth Annual International Conference of the African Association for Lexicography (AFRILEX), which was held at the Nelson Mandela Metropolitan University, Port Elizabeth, South Africa, 2-5 July 2013.
\end{abstract}

Lexikos 23 (AFRILEX-reeks/series 23: 2013): 1-28 
names, transliteration table, etc.). Although the AWS is not a dictionary, it also contains a word list. Words which present spelling problems, neologisms and items requiring recognition as part of the Afrikaans vocabulary are some of the categories considered for inclusion in this list.

In 2004 the NLBs of the other nine official African languages started with the revision of the spelling and orthographic rules of these languages. The first editions were published by PanSALB in 2008. No revisions have been compiled since. The AWS could serve as example of what could be done for the other African languages and even the Khoe and San languages.

Keywords: ALPHABET, LANGUAGE CHANGE, LEXICOGRAPHER, LEXICOGRAPHY, ORTHOGRAPHY, SIMPLIFIED LANGUAGE, SPELLING, STANDARDISATION, TERMINOGRAPHERS, TERMINOGRAPHY, TRANSLITERATION

Opsomming: Die Afrikaanse spel- en skryfreëls as voorbeeld vir ander Suid-Afrikaanse tale. Die spel- en skryfreëls van 'n taal is baie belangrik vir die samestellers van algemene en vakwoordeboeke. Wanneer 'n woordeboek saamgestel word, moet die leksikograwe en terminograwe by hierdie reëls hou. Die woordvormingsbeginsels van 'n taal vorm deel van hierdie reëls en nuwe terme kan slegs in 'n gegewe taal geskep word as die spel- en skryfreëls van die taal gevolg word.

In hierdie artikel word van werk aan die Afrikaanse spel- en skryfreëls in breë trekke verslag gedoen. Hopelik kan sommige van die lesse wat in dié proses geleer is as riglyne dien vir parallelle prosesse van die standaardisering van die spel- en skryfreëls van die ander Suid-Afrikaanse tale.

Met die stigting van die Nasionale Taalliggaam vir Afrikaans (NTLA) van die Pan- SuidAfrikaanse Taalraad (PanSAT), is daar besluit dat die lede van die Taalkommissie van die SuidAfrikaanse Akademie vir Wetenskap en Kuns (SAAWK) lede sou word van die NTLA. Hierdie lede het toe die Tegniese Komitee Standaardisering (TK: Standaardisering) geword. Sedert sy totstandkoming het die lede van die Taalkommissie cum TK: Standaardisering (Kommissie) voortgegaan met hul werk aan die standaardisering van die spel- en skryfreëls van Afrikaans. Saam met die werk aan spel- en skryfreëls is die langtermyndoelwitte wat deur die Kommissie gestel is, onder andere om die die Afrikaanse Woordelys en Spelreëls (AWS) te wysig en aan te pas om dit in 'n elektroniese formaat en aanlyn beskikbaar te stel en om 'n standaardgrammatika vir Afrikaans saam te stel wat internasionaal op die Internet toeganklik kan wees.

Die AWS is 'n bron wat deur die Kommissie saamgestel word om gebruikers van Afrikaans te help wanneer hulle die standaardvariëteit van die taal gebruik. Die AWS verduidelik die grondreëls van die Afrikaanse spel- en skryfkonvensies. Die basiese reëls is in vereenvoudigde taal geskryf.

Geen taal is staties nie en taalverandering moet gedurig in gedagte gehou word. Die woordeskat en uitspraak van ' $n$ dinamiese taal kan oor ' $n$ tydperk verander. Hierdie veranderinge moet in die spel- en skryfsisteem van die taal weerspieël word.

Hierdie artikel behandel aspekte soos die voorwerk van die AWS, spel- en skryfbeginsels en -reëls, agterwerk (bv. 'n lys afkortings, 'n lys internasionale plekname, transliterasietabelle, ens.). Hoewel die AWS nie 'n woordeboek is nie, bevat dit ook 'n woordelys. Woorde wat spelprobleme oplewer, neologismes en gevalle wat erkenning as deel van die Afrikaanse woordeskat verdien, is sommige van die kategorieë wat oorweeg word vir insluiting in hierdie lys.

In 2004 het die NTL'e van die ander nege amptelike Afrikatale begin met die hersiening van die spel- en skryfreëls van hierdie tale. Die eerste uitgawes is deur PanSAT in 2008 gepubliseer. 
Geen hersienings is sedertdien saamgestel nie. Die AWS kan as voorbeeld dien van wat vir die ander Afrikatale gedoen kan word.

Trefwoorde: ALFABET, LEKSIKOGRAAF, LEKSIKOGRAFIE, ORTOGRAFIE, SPELLING, STANDAARDISERING, TAALVERANDERING, TERMINOGRAAF, TERMINOGRAFIE, TRANSLITERASIE, VEREENVOUDIGDE TAAL

\section{Introduction}

Throughout the ages mankind had the urge to depict their thoughts, ideas, stories and history. Speech had to be reduced to writing. Different cultures developed different writing systems (i.e. cuneiform writing, hieroglyphs, alphabets, etc.). Writing systems had to be standardised to allow for proper communication through encoding and decoding principles and practices.

The English term 'orthography' dates from the 15th century. It comes from the Latin 'orthographia', which derives from the Greek 'orthós' (correct) and 'gráphein' (to write). The term 'orthography' refers to the correct or conventional way of spelling and the study or science of spelling. Orthography describes or defines the set of symbols used in writing a language, and the rules how to use these symbols.

Most significant languages in the modern era are written down, and for most of such languages a standard orthography has developed. The standard orthography is often based on a standard variety of the language and thus exhibiting less dialectal variation than the spoken language (http://en.wikipedia. org/wiki/orthography, 2013).

In some cases orthographies are regulated by bodies such as language academies or government agencies. For many languages (including English) there are no such authorities, and orthographies develop through less formal processes (cf. http://en.wikipedia.org/wiki/orthography, 2013).

The spelling and orthographic system of a language is just as integral a part of the language as its vocabulary. Language users create or are involved in the process of creating the spelling and orthographic system of their language, and they should be familiar with the approved spelling and orthographic system to enable them to read and write. A standard(ised) spelling and orthographic system should be used in the public domain for instance by educators, language practitioners, the media and government.

Language users are involved in any changes that may occur in the spelling and orthographic system. Since language is dynamic, it is quite natural for the vocabulary, spelling and orthography of a language to change. These changes are mirrored especially in the way that the spelling system of a language adapts according to development and modernisation.

Language modernisation is viewed as a complex and multi-dimensional endeavour whose sole aim is the empowerment of any language for literacy and numeracy for all purposes in formal and informal education (Emenanjo 
1998: 44). Usually the basic spelling and orthographic policies and principles remain unchanged, but when the language develops and modernises, this process usually has an effect on the spelling and orthography.

New and unified spelling and orthographic systems should be created for the languages selected for standardisation. Establishing standardised, efficient and practical spelling and orthographic rules is a crucial basis for developing a modern literacy tradition.

In its pristine sense, literacy is concerned with the issues of writing and reading. Writing presupposes a universally accepted writing system, while writing and reading presupposes both a standard(ised) variety and texts in that variety (Emenanjo 1998: 44).

An orthography is to literacy what numeration is to numeracy (Emenanjo 1998: 47).

An efficient and practical spelling and orthographic system is a direct function of enabling languages in educational, cultural, administrative and mass media systems in the countries concerned (Abdulaziz 1989). Standardised spelling and orthographic rules assist with the production of texts in the standard variety of a language. They also assist in the process of developing standardised curricula designed for formal education.

According to Emenanjo (1998: 52), education is the acquisition of permanent numeracy and literacy and the integrated development of the cognitive, affective and psycho-motor domains in humans. The language of achieving these is immaterial, but it is better in the person's mother tongue or the language of the immediate community (cf. Prah 1993, 1995a and 1995b). It is therefore necessary to provide spelling and orthographic rules in the various official languages of South Africa.

In South Africa there is a dire need for reliable orthographic, spelling and editing rules for all the official languages. Documents dealing with spelling rules do exist in all these languages but most of these documents are outdated, need to be revised and modernised urgently and are not as comprehensive as they should be in order to address current needs in the various fields of communication and knowledge dissemination.

Language cannot be used in written communication or documented in dictionaries if the spelling and orthographic rules are not standardised. New terms that are created need a solid linguistic basis with proper word-forming principles as norm. Lexicographers of the various National Lexicography Units (NLUs), other lexicographers and terminographers cannot compile dictionaries for Afrikaans and the other African languages without standardised spelling and orthographic rules. Lexicographers and terminographers adhere to the spelling and orthographic rules of the standard variety of a language when compiling dictionaries. Translators cannot translate, editors cannot verify and edit and publishers cannot publish without standardised spelling and orthographic rules. 
Without a proper spelling and orthographic system users of the language would all spell and write in a haphazard way. The Afrikaans language for instance developed from what was regarded as a mere "kitchen language" to a standard language that can be regarded as a language of science and technology. While the Dutch-Afrikaans language developed, there were many attempts to standardise the spoken language into a written variety. Many of these attempts failed, and since there was no authority taking charge of the process, different varieties resulted, i.e. 'Maleierafrikaans', 'Griekwa-afrikaans', 'Oosgrensafrikaans', 'Bolandafrikaans', 'Oranjerivierafrikaans', 'Vrystaatafrikaans', 'Transvaalafrikaans', etc. There was no uniform language, but considerable usage and pronunciation differences and no uniform orthography (cf. McLachlan 2001: 2). It was obvious that everyone wrote the language as he/she deemed fit since there was no 'Standaardafrikaans' variety.

The first Afrikaanse Woordelijs en Spelreëls was published in 1917 by request of the Suidafrikaanse (sic) Akademie vir Taal, Lettere en Kuns. This publication was the product of the language pioneers known as Die Genootschap van Regte Afrikaners that was established on 14 August 1875 and the Kommissie voor Taal en Letteren of the Suidafrikaanse (sic) Akademie vir Taal, Lettere en Kuns (cf. McLachlan 2001: 2).

There were originally two commissions associated with the Suid-Afrikaanse Akademie vir Wetenskap en Kuns (SAAWK) (South African Academy for Science and the Arts): one to give attention to the development of spelling rules for the new Afrikaans language and another to compile a word list of existing Afrikaans words. The two commissions later merged and the SAAWK established the Taalkommissie (Language Commission) (De Bruyn 2013).

The first legislation that sanctioned the standardisation of Afrikaans spelling and orthographic rules was Act 23 of 1921 that gave the SAAWK statutory status to develop and standardise Afrikaans (Kapp 2009: 53; McLachlan 2001: 1). Since the first 1917 edition, nine revised editions of the Afrikaanse Woordelys en Spelreëls (AWS) (Afrikaans Word List and Spelling Rules) were published.

With the establishment of the Pan South African Language Board (PanSALB), that resulted from the recent South African Constitution, its legislation, i.e. Act 59 of 1995 as amended in 1999, gives this organisation the legal authority to establish standardising bodies, i.e. the National Language Bodies (NLBs), for each of the official languages as well as for the Khoe and San languages and the South African Sign Language (Alberts 2005).

The National Language Bodies were established by notice in the Government Gazette in terms of section 8(8)b of the Pan South African Language Board Act, Act No. 59 of 1995 (Alberts 2005). PanSALB published Norms and Rules in the Government Gazette No. 21907 of 22 December 2000 to ensure that the NLBs are established primarily as language development agencies with special emphasis on standardisation in respect of all official languages, the Khoe and San languages and South African Sign Language (Alberts 2005). 
There is a distinct need for a reliable document on orthographic, spelling and editing rules for each of the official languages and the Khoe and San languages in line with what Afrikaans has:

Language cannot be used in written communication or documented in dictionaries if the spelling and orthographic rules are not standardised. New terms that are created need a solid linguistic basis with proper word-forming principles as norm. ... Although the original establishment of Afrikaans as a language in itself was disputed, Afrikaans is now a fully-fledged standard and scientific language. In 1912 the argument was used against the use of Afrikaans at tertiary level, that 'Afrikaans is nie deftig genoeg nie'. (Finlayson 2004)

The legislation on the Pan South African Language Board (PanSALB), Act 59 of 1995 as amended in 1999, made provision for the incorporation of existing standardisation bodies in the newly established National Language Bodies (NLBs). With the establishment of the National Body for Afrikaans (NLBA) of PanSALB it was therefore decided that the members of the Taalkommissie (Language Commission) of the Suid-Afrikaanse Akademie vir Wetenskap en Kuns (SAAWK) would become members of the NLBA. These members then constituted the Technical Committee for Standardisation (TC Standardisation).

Since its establishment the members of the Taalkommissie cum TC for Standardisation (Commission) continued with their work on the standardisation of the spelling and orthographic rules for Afrikaans. The members worked in close collaboration with the SAAWK and PanSALB and two revisions of the Afrikaanse Woordelys en Spelreëls (AWS) were published since.

Although there was a unanimous agreement in 2001 that the work of the Commission should be continued without interruption, it transpired in recent years that PanSALB could not afford two meetings per annum as was required. The SAAWK resumed with its funding of the Commission's meetings due to the long-term objectives set by the Commission (e.g. the conversion and adaptation of the AWS to an electronic format to be made available as an electronic book (e-book) and online, as well as a request for a standard grammar for Afrikaans to be compiled for international access on the Internet). The SAAWK had no choice but to assist with the financing of the activities since these activities had reached a critical stage of implementation, for which the momentum and continuity could be lost at that stage if the set time frame was to be kept.

An important aspect of the planning was the need for co-opted expertise and the utilisation of experts who have been involved in the compilation of the recently published AWS (2009). This aspect was recognised by PanSALB and was also an important consideration for the co-operation between the SAAWK and PanSALB. The SAAWK initially agreed to share the funding of the work of the Commission on a 50/50 basis by taking responsibility for one of the two meetings scheduled per year. In recent years most meetings and activities of the Commission were funded by the SAAWK.

The structure of the Commission needs urgent attention. Over a period of 
time seven of the eight members of the Commission who held membership of both the Taalkommissie of the SAAWK and the NLBA of PanSALB decided not to serve another term of office on the Taalkommissie. In 2013 a new Taalkommissie was appointed by the SAAWK and only one member of the original Commission remains on both the Taalkommissie and NLBA. The other members of the TC: Standardisation are therefore no longer serving on the Taalkommissie. This issue is already being addressed by the SAAWK and PanSALB.

Work on the Afrikaans spelling and orthographic rules are discussed in this article to serve as a guide for similar work in the other South African languages. It should be noted that Afrikaans, a language with its roots in Africa, is also recognised as an African language by the Department of Basic Education. However, in the context of this article, the term 'African languages' refers to the nine indigenous Bantu languages of South Africa that received official language status according to Section 6(2) of the Constitution of the Republic of South Africa, 1996 (cf. 2.2).

\section{Historical background of the spelling and orthography of Afrikaans and the African languages}

\subsection{The spelling and orthography of Afrikaans}

The Suid-Afrikaanse Akademie vir Wetenskap en Kuns (SAAWK) (South African Academy for Science and the Arts) was established on 2 July 1909. At that stage English and Dutch were the official languages of South Africa. Afrikaans became one of the three official languages in 1925 (cf. Kapp 2009: 54) and it was only in 1983 that Dutch was officially removed as an official South African language.

The Union Parliament of South Africa was not in favour of bilingualism (English and Dutch) or mother-tongue education. There was a language dispute over language in education that lasted since 1906. Although regarded by some as a mere "kitchen language", the Afrikaans language started to develop rapidly alongside Dutch. The Afrikaans speaking community wanted Dutch (read also Afrikaans) to become a compulsory language in mother-tongue education (cf. Kapp 2009: 103-108).

Although Afrikaans was not an official language at the time, preliminary work on the Afrikaans spelling and orthographic rules started in 1875. Since 1911 several requests were made to the SAAWK to standardise the Afrikaans spelling and orthographic rules, but seeing the unsettling relationship between Dutch and Afrikaans speaking groups, these requests were for the time being ignored. The SAAWK, however, took an official decision in 1914 to standardise the spelling and orthographic system of Afrikaans. The Kommissie voor Taal en Letteren (Commission for Language and Literature) (later called the Taalkommissie (Language Commission)) was established to compile the first rules on Afrikaans spelling and orthography (Kapp 2009: 161) and the first version of 
the Afrikaanse Woordelys en Spelreëls (AWS) was published in 1917 (cf. Kapp 2009: 111) in co-operation with the members of Die Genootschap van Regte Afrikaners (McLachlan 2001: 2).

One of the small steps towards the recognition of Afrikaans as an official language next to English and Dutch was taken in 1917 when copies of the first edition of the AWS were made available to teachers and schools (cf. Kapp 2009: 106, 329).

The legislation regarding the statutes of the SAAWK, Act 33 of 1956, and the legislation on the establishment of the SAAWK, Act 54 of 1956, stipulate that the Afrikaans spelling and orthographic rules of the standard variety of Afrikaans, as standardised by the Taalkommissie of the SAAWK, are enforceable and should be followed by government and general users of Afrikaans. The Taalkommissie should also prove through excellent linguistic example, the directional role of its own publications (e.g. the AWS) and the work of this commission that it deserves to be the standardisation body for Afrikaans (Kapp 2009: 135-136; 323). The legislation was repealed and currently there is no other legislation in place to support the work of the Taalkommissie other than it being part of the TC: Standardisation of the Afrikaans NLB (NLBA) of PanSALB (cf. Introduction).

Several revisions of the AWS were published since 1917 and all these represented the diachronic and synchronic development of the standard variety of the Afrikaans spelling and orthographic system. Since the first publication of the AWS, the Taalkommissie (read also Commission) continued with the standardisation work and endeavoured to eliminate practical spelling and orthographic problems as far as possible and to bring solutions where problems were encountered (cf. McLachlan 2001: 2). Although the Commission's main focus is Standard Afrikaans, it also concentrates on different varieties of Afrikaans (cf. De Bruyn 2013).

The ninth revision of the AWS was published in 2002 and in 2003 the members of the Taalkommissie received the SAAWK C.J. Langenhoven prestigious award. Each member received a medal and certificate.

The 2002 publication was a total reworking of the 1991 publication and all spelling and orthographic rules were rewritten in simplified language. The 2002 revision elaborated on some aspects of the spelling and orthographic system and revisited anomalies in previous revisions. The Commission consulted widely with language practitioners and stakeholders before the publication of the book.

In 2004 PanSALB decided to revise the spelling and orthographic rules of the nine official African languages. Copies of the 2002 version of the AWS were presented to members of the TC Standardisation of all the NLBs at the 2004 consultative meeting of PanSALB which was organised to discuss the revision process.

In August 2006 the Afrikaanse Taal- en Kultuurvereniging (ATKV) awarded an award to the Taalkommissie for the revision and compilation of 
the 2002 edition of the AWS. The tenth revision of the AWS was published in 2009 to coincide with the centenary of the SAAWK. The members of the Taalkommissie were rewarded for this effort with the SAAWK C.L. Engelbrecht prestigious award. The fact that the Taalkommissie received prestigious awards for the compilation of the 2002 and 2009 editions of the AWS is a sure indication that these products met the needs of the target users.

The tenth revision of the AWS was published in 2009 to coincide with the centenary of the SAAWK. The members of the Commission were rewarded for this effort with the SAAWK C.L. Engelbrecht prestigious award.

No language is static and there are always language changes to be taken into consideration. The vocabulary and pronunciation of a dynamic language could change over a period of time. These changes should be reflected in the spelling and orthographic system of the language. The revision of the Afrikaans spelling and orthographic rules is therefore an ongoing process.

\subsection{The spelling and orthography of the African languages}

Originally the activities of early missionaries transmuted the various indigenous African languages to written languages. The speakers of the languages provided the vocabulary and the missionaries the orthographies and grammar (cf. Ranger 1989).

These missionaries were dealing with foreign languages and they had little knowledge of the history, genesis, or linguistic or political boundaries of the languages. The transmutation and codification of the languages were marred by a number of discrepancies. Each missionary used the orthography which was informed by his linguistic background, and the same words were spelt differently by the different missionaries (cf. Msimang 1998: 169-171).

Several scholars of the indigenous South African languages had since the attempts by the missionaries tried to develop spelling and orthographic rules for these languages. Spelling and orthographic conventions are also embedded in the grammar of these languages (cf. Msimang 1998: 169; Poulos and Louwrens 1994; Poulos and Msimang 1998).

In 1928 the Union government convened an Advisory Committee on Bantu Studies and Research to harmonise the orthographies of the African languages. This was followed by the appointment of the Suto-Pedi-Chuana Subcommittee, to formulate a uniform orthography for the three Sotho languages, i.e. Southern Sotho (Sesotho), Northern Sotho (Sesotho sa Leboa/Sepedi) and Tswana (Setswana). However, the representatives of the three language groups differed so much that the orthographies that were drawn up by this committee could not be accepted (cf. Msimang 1998: 170).

In 1948 the Transvaal Education Department expressed a need for a conference on reducing orthographic differences between the three Sotho languages, and the resolutions taken at the Somerset House Conference formed the basis for the Sotho Terminology and Orthography No. 1 published in 1951 by 
the Transvaal Education Department and in 1957 by the Department of Native Affairs. This Department also published the Zulu/Xhosa Terminology and Orthography No.1 in 1957 (cf. Msimang 1998: 170).

During the previous dispensation there was an official attempt by the former Language Boards of the former Department of Bantu Education to standardise the vocabulary, spelling and orthography of the various indigenous languages. The products of these attempts by the Language Boards were published by the Department of Bantu Education as booklets on "Terminology and Orthography" and several revisions were published in the indigenous African languages (cf. Departmental Northern Sotho Language Board 1988).

The Constitution of the Republic of South Africa, 1996, provides for the equitable use of all the official languages of the country, and for the promotion and development of the historically marginalised indigenous languages. According to section 6(1) of the Constitution, the official languages of South Africa are Sepedi, Sesotho, Setswana, Siswati, Tshivenda, Xitsonga, Afrikaans, English, isiNdebele, isiXhosa and isiZulu. Apart from the 11 official languages, the Constitution also recognises other languages such as Khoe and San and the South African Sign Language, which should be promoted and developed. The National Language Policy Framework of March 2003 gives effect to the constitutional rights regarding language usage and development (cf. Department of Sport, Recreation, Arts and Culture 2005: 1,3).

Section 6(2) of the Constitution of the Republic of South Africa, 1996, recognises the historically diminished use and status of the indigenous languages of South Africa, and compels the state to take practical steps to design mechanisms to elevate the status and advance the use of these languages (cf. Department of Sport, Recreation, Arts and Culture 2005: 3). The Constitution further requires all official languages to enjoy parity of esteem and be treated equitably. It also provides for national government to regulate and monitor the use of official languages by legislative and other means (cf. Department of Arts and Culture 2011: 7; Government Gazette 2012: 2, 4). The Use of Official Languages Act, 2012 (Act No. 12 of 2012) stipulates that every national department, national public entity and national public enterprise should develop a language policy regarding its use of official languages, amongst others, in effectively communicating with the public, official notices, government publications and inter- and intra-government communications (cf. Government Gazette 2012: 6; cf. Regulation 7(1)(d) Government Gazette 2013: 25). The development and modernisation of the vocabulary, and of the spelling and orthographic rules of the official languages give effect to the constitutional rights of languages regarding the usage and their further development.

The Language Boards were replaced by the National Language Bodies (NLBs) of PanSALB and according to the NLBs the terminology and orthographic lists compiled by the former Language Boards were outdated and had to be revised.

The Strategic Plan of the National Language Bodies that was approved at 
the Pan South African Language Board meeting of 19 March 2004 stated that special attention should be paid to the revision of the spelling and orthographic rules of the official African languages (cf. Alberts 2005).

A special consultative meeting was therefore held on 1-2 July 2004 in Pretoria to discuss the revision process with representatives of the Technical Committees (TCs): Standardisation of all the National Language Bodies. PanSALB regarded the NLBs to be well-positioned to deliver products with normative rules on spelling and orthography for each of the official African languages that would enhance communication in South Africa since the NLBs are regarded as the custodians of the languages (cf. Alberts 2006a).

As members of PanSALB structures, i.e. the Technical Committees: Standardisation of the National Language Bodies, the NLBs were the main bodies entrusted with the standardisation of the official languages, the Khoe and San languages and the South African Sign Language. They had to decide on the degree of revision that was needed for the respective languages. Some of the National Language Bodies had already started on their own with the revision of the spelling and orthographic rules of their respective languages before they were officially requested to do so at the consultative meeting of July 2004 (cf. Alberts 2006a).

During the consultative meeting of July 2004 members of the Khoe and San NLB indicated that they felt the need for and were eager to start with the compilation of spelling and orthography rules for these languages (cf. Alberts 2006a). Unfortunately no rules were compiled to date.

The process of the revision of the spelling and orthography rules of the nine official African languages entailed the standardisation as well as the modernisation of the existing rules. PanSALB embarked on this project by officially requesting the National Language Bodies to revise the current spelling and orthographic rules. During this process, the PanSALB structures (e.g. the National Language Bodies (NLBs), the Provincial Language Committees (PLCs), and the National Lexicography Units (NLUs)) collaborated with stakeholders in the various language communities, and with the national and provincial Departments of Arts and Culture, of Education, and of Communication (cf. Alberts 2006a).

The NLBs working on the three languages with cross-border varieties in Lesotho, Botswana and Swaziland, i.e. South Sotho/Sesotho, Setswana and Siswati, attempted to revise the spelling and orthographic rules in conjunction with the language boards or similar structures of these countries. The Swaziland Language Board attended the meetings of the Siswati NLB and the resulting spelling and orthographic booklet is a joint effort by South Africa and Swaziland. The Setswana spelling and orthography revision is also a joint effort by South Africa and Botswana. The same, however, is not true regarding the revised Sesotho spelling and orthographic rules (cf. Alberts 2006). Attempts to harmonise the orthographies of the South African and the Lesotho varieties of South Sotho/Sesotho, which were introduced as far back as 1927 have always 
met with resistance from Lesotho although these varieties are almost identical dialects of the same language (cf. Msimang 1998: 167). To date the South African and Lesotho orthography unfortunately still remains different.

The final revised spelling and orthography documents for each of the nine official African languages could be regarded as products of consultation of which the different speakers of the nine official African languages could rightfully claim ownership.

The focus of the revision process was on spelling, orthographic and editing rules. The project teams revisited and revised existing documents on spelling, orthographic and editing rules. The project teams also focused on naming and word-forming principles and on abbreviation and punctuation principles. The Technical Committees charged with standardisation addressed aspects such as:

- spelling rules (e.g. hyphen; apostrophe; capital letters (first letter of sentence, nationalities and tribal designations, names of languages, proper nouns, qualifiers of capitalized proper nouns, names of days, toponymic guidelines); word division (parts of speech, demonstrative pronouns, auxiliary formatives, abbreviated forms, numerals, abbreviations));

- orthographic rules (e.g. vowels; consonants (e.g. plosives); constituents (e.g. fricatives, liquids, nasals, affricates, semi-vowels); clicks);

- typography (the spelling and orthographic rules regarding place names, surnames, street names, month names, day names, names of geographical features, etc.);

- punctuation norms;

- abbreviation norms;

- terminology lists (explaining of the grammar terms being used when dealing with the different rules);

- word lists (containing difficult words or words easily or usually misspelt);

— lists of abbreviations and acronyms (cf. Alberts 2006b).

Of these issues the top three were regarded as the urgent ones for the first stage of the revision process. In cases where little or no revision was needed, the TCs could devote more time to the latter issues. All these aspects were (and will in future again be) researched, discussed, verified and authenticated by the various NLBs (cf. Alberts 2006b).

The revised spelling and orthographic rules should depict the changes in the relevant languages throughout the past decades. Each National Language Body had tried to capture the dynamic growth of the language concerned.

This process of standardising the languages and revising the current spelling and orthographic rules is supposed to be ongoing. The PanSALB Board decided that the NLBs would in future attempt to keep abreast of 
changes in the spelling and orthography by incorporating changes in each revised version of the spelling and orthographic rules (cf. Alberts 2006b).

Before its publication, the first project output of nine draft booklets were disseminated to stakeholders such as language practitioners, journalists, educators, the media, etc. for their input. Consultative meetings were held with these stakeholders and comments were dealt with by their incorporation into the booklets (cf. Alberts 2006b).

In September 2008 PanSALB published the revised versions of the spelling and orthographic rules to serve as easy reference resources to the spelling and orthographic rules of the nine official African languages (cf. PanSALB 2008). PanSALB then expressed its wish that these documents could be used as quick reference tools. These guideline documents on spelling and orthography had been compiled to serve as booklets for use by language users.

PanSALB stipulated that each National Language Body will have to submit a revised version at the end of its five-year term of office. The NLBs of the official African languages started in 2004 with the first revision of the spelling and orthographic rules of these languages, and the first editions were published by PanSALB in 2008 but no revisions were compiled or published since.

Since the revision of the spelling and orthographic rules was regarded as an ongoing process, PanSALB further stipulated that it would welcome comments from users. These comments could assist the NLBs with the future revision of the rules. After the publication of the booklets, PanSALB did receive feedback from several users. Some of the feedback was positive, but most of it extremely negative and seeing that no revisions were compiled since, the valuable feedback was disregarded.

This article focuses on the post-1994 situation regarding the development and/or standardisation of orthographies for the (official) South African languages. The continued work on the Afrikaans orthography and the resulting products can serve as an example of how and what could and should be done regarding the development and/or revision of the spelling and orthographic rules of the other nine official African languages and the Khoe and San languages.

\section{Aspects of the work on the AWS}

\subsection{Background}

The Afrikaanse Woordelys en Spelreëls (AWS) is a resource compiled by the Taalkommissie (Language Commission) (cf. Pharos 2009) to assist users of Afrikaans in using the standard variety of the language. The AWS explains the ground rules of the Afrikaans spelling and orthographic conventions.

The basic rules are provided in simplified language for easy comprehension and application.

The current Commission, consisting of academics, translators, lexicogra- 
phers and terminologists, decided to contact language practitioners and academics before publishing the 2002 and 2009 revisions. The aim was to get the input of the language experts on the changes incorporated in these publications. Valuable comments and contributions were received which were incorporated in these publications.

The Commission meets twice a year for a full week to decide inter alia which new words should be incorporated as part of the vocabulary of Standard Afrikaans, how to spell these words, and how to standardise Afrikaans in general (cf. De Bruyn 2013).

\subsection{Front matter}

The front matter contains an acknowledgement to financial contributors (i.e. financial assistance by Die Dagbreek Trust, Het Jan Marais Nationale Fonds, the University of Pretoria, and PanSALB) and computer assistance (i.e. the computer expertise from the Centre for Text Technology (CText) of Northwest University).

The front matter also contains a Table of Contents; Preface; Suggestions for Users; Explanations; Modus operandi; and Ground rules of the Afrikaans spelling system.

\subsubsection{Table of contents}

The table of contents contains acknowledgements; a preface; suggestions for users; explanations; the modus operandi; ground rules of the Afrikaans spelling; the basic spelling and orthographic rules in an alphabetical format; a word list containing examples of the Afrikaans vocabulary; a list of abbreviations; a list of international place names; a transliteration table; colloquial Afrikaans; a terminology list, and an index.

\subsubsection{Preface}

The preface gives a synopsis of the process regarding the standardisation of the Afrikaans language. It provides a broad outline of the work on the AWS and the influence of language development and change on the spelling and orthographic conventions.

The preface also contains the names of the current members of the Commission who compiled the latest edition of the AWS.

\subsubsection{Suggestions for users}

The suggestions for users assist the users of the AWS by providing a basic style guide. 


\subsubsection{Explanations}

This section describes the various sections contained in the AWS. It explains the basic spelling and orthographic conventions of Afrikaans and provides a list of phonetic signs with their appropriate pronunciation in Afrikaans, e.g. [æ] skêr, bêre; [u:] loer; [ $\varepsilon]$ sê, hê.

The AWS is not a dictionary but it contains a word list. This section explains why certain Afrikaans words are included in the word list while others were omitted.

\subsubsection{Modus operandi}

This section explains how the Taalkommissie functions. The different Commissions responsible for the different revisions and publications of the AWS inherited the basic core of the AWS. This core was either kept intact or changed according to language change and modernisation.

The Commission had to take different aspects into consideration - it should not only give advice on how to spell but also what to spell. Obsolete words had to be deleted and neologisms entered.

\subsubsection{Ground rules of the Afrikaans spelling system}

An outline is provided of the ground rules of the Afrikaans spelling and orthographic system. There are three basic principles which have been kept almost intact since the first AWS publication of 1917. The spelling and orthography of the standard variety of Afrikaans are still determined by these ground rules although they were refined throughout the years:

(a) The current spelling and orthography of words are determined by the tradition of how Standard Afrikaans words are spelt and written.

(b) The spelling of Afrikaans is based on the phonetic system of Standard Afrikaans.

(c) Uniformity: words that have related forms should, whenever possible, be spelt the same.

\subsection{Spelling and orthographic rules}

The previous formats of the spelling and orthographic rules, i.e. editions prior to the 2002 and 2009 publications of the AWS, were very difficult to comprehend. The Commissions working on the latest editions decided to rewrite all spelling and orthographic rules in a format that the average grade 10 learner and most users of the Afrikaans language would be able to comprehend. The rules are therefore rewritten in simplified language. Rules are also shorter and 
hidden rules gained proper rule status.

The rules of the latest versions of the AWS are presented in a user-friendly alphabetical and numerical order. The rules are arranged in an alphabetical sequence to allow for easy access to information (i.e. 1. Afbreek van woorde; 2. Afkappingsteken; 3. Afkortings; 4. Akuutteken; 5. Deelteken; ... 17. Wisseling; 18. Woorde van vreemde herkoms). All rules are numbered under the alphabetically arranged category i.e. 1. Afbreek van woorde: Reël 1.1, Reël 1.2, Reël 1.3, etc. Several empty lemmas were entered in the 2002 edition of the AWS, i.e. Aanmekaarskryf. A cross-referencing system assisted the user in finding information on this lemma, and others that were not provided in the alphabetical arrangement, e.g. Aanmekaarskryf see Skryfwyse - los en vas. The 2009 edition of the $A W S$ does not contain any empty lemmas.

Orientation paragraphs and some comments supply extra information. Examples of words spelt according to the specific rule are provided. Examples of misspelt words are sometimes also supplied and these are marked with asterisks to indicate that they are wrongly spelt. The reasoning behind providing misspelt words was that users frequently learn more from these wrongly spelt examples than from the correctly spelt examples, i.e.:
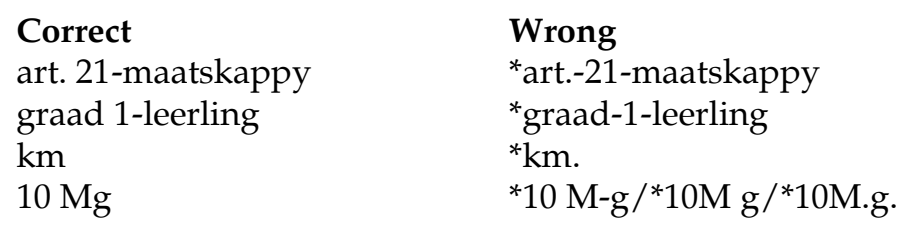

\subsubsection{Afbreek van woorde (Division of words)}

There might not be enough space in written, typed or printed texts to fit a full word in a given line. Such words should preferably be shifted in full to the next line. Words can, however, be divided according to the rules provided in this section, i.e.

bio-chemie, nooiens-van, voet-stappe (Rule 1.3)

ge-sel-se-ry, tran-sak-sie, vrien-din (Rule 1.4)

bak-ke, bor-rel, mon-nik (Rule 1.10)

beeld-jie, koord-jie, land-jie (Rule 1.14)

\subsubsection{Afkappingsteken (Apostrophe)}

This section deals with the use of the apostrophe in Afrikaans, e.g.

foto's - foto'tjie, radio's - radio'tjie (Rule 2.1)

hoera's, karba's - karba'tjie (Rule 2.7)

crèche'e or crèches, garage - garage'ie (Rule 2.8)

a's - a'tjie, l'e or l's - l'etjie (Rule 2.11) 
gr. 12's, .303's, .22's, 747's (Rule 2.14)

g'n (geen), 'k (ek), s'n (syne), 't (het) (Rule 2.15)

\subsubsection{Afkortings (Abbreviations)}

A representative list of abbreviations and acronyms is provided in the back matter of the AWS. Although the abbreviations of proper names and of political parties are not included in the list, names of some institutions that may no longer exist or that were renamed (i.e. EVKOM, YSKOR, ZARP), are included for historical purposes since users may still find these in documents such as historical or literary texts.

The rules governing Afrikaans abbreviations and acronyms are provided in the 'Afkorting' section, i.e.:

chem. (chemie; chemies(e)), elektr. (elektries(e)) (Rule 3.1)

bg. (bogenoemde), kl. (kleinletter) (Rule 3.2)

a.g.v. (as gevolg van), o.a. (onder andere) (Rule 3.4)

BA or B.A. (Baccalaureus Artium) (Rule 3.8)

HOD or H.O.D. (Hoër Onderwysdiploma) (Rule 3.9)

SADOU or Sadou (Suid-Afrikaanse Demokratiese Onderwysersunie) (Rule 3.10)

\subsubsection{Akuutteken (Acute accent)}

The acute accent (') is only placed in Afrikaans on vowels and diphthongs, e.g.

én ... én, óf ... óf; déúr, kóúd, kráái; kóéël, réën (Rule 4.2)

dié, hiér (Rule 4.3)

attaché, cliché, née (Rule 4.4)

\subsubsection{Deelteken (Diaeresis)}

The diaeresis ("*) is placed in Afrikaans on vowels, but only in certain circumstances and it has different usages in Afrikaans spelling conventions, i.e.:

beëdig, drieërlei, geëis, trofeë; altruïs; reünie (Rule 5.1)

essensieel > essensiële; finansieel > finansiële (Rule 5.2; 5.3)

biëlektries or bi-elektries; poliëtileen or poli-etileen (Rule 5.6)

fee $>$ feë, see $>$ seë; genie $>$ genieë, knie $>$ knieë (Rule 5.10)

\subsubsection{Diftonge (Diphthongs)}

The spelling of diphthongs is unproblematic in Afrikaans and it is only the diphthong [əi] that is sometimes spelt with ei and sometimes with $\mathbf{y}$, cf.

brei/bry, lei/ly, steil/styl, wei/wy (Rule 6.1) 


\subsubsection{Getalle, syfers en simbole (Numbers, figures and symbols)}

The rules in this section provide direction on how to write words and groups of words in combination with numbers, figures and symbols, i.e.:

A4-formaat, 7-sitplekvoertuig; 6-erig, 14-jarige, $\Delta$-agtige (Rule 7.1)

$16,7 \mathrm{~kg}, 318,55 \mathrm{~kW} ; 1,5$ l, R22,75 (Rule 7.4)

$0,9 \mathrm{~m} /{ }^{*}, 9 \mathrm{~m} ; \mathrm{R} 0,25 /{ }^{*} \mathrm{R}, 25 ; 0,5 \mathrm{c} /{ }^{*}, 5 \mathrm{c}$ (Rule 7.5)

2009-11-25 for 25 November 2009 (Rule 7.7)

03:15 for quarter past three in the morning (Rule 7.8)

$5{ }^{\circ} \mathrm{C}$-styging; 50 kg-sakke; $750 \mathrm{~m} \ell$ koeldrank (Rule 7.17)

\subsubsection{Gravisteken (Grave accent)}

The grave accent (') is used in Afrikaans on vowels only, e.g.:

appèl, dè, hè, nè (Rule 8.1 )

crèche, pietà, première, vis-à-vis (Rule 8.2)

\subsubsection{Hoof- en kleinletters (Upper and lower case letters)}

The use of upper and lower case letters relies on convention. The AWS provides guidelines on the usage of upper and lower case letters but specific institutions may have in-house style guides which could influence usage. Rules 9.1-9.26 deal with a variety of issues, i.e.

- The beginning of sentences (Rules 9.1-9.2)

- Proper names (Rule 9.3)

- Form of address (Rules 9.4-9.6)

- Animal and plant names (Rules 9.7-9.8)

- Appellative nouns used as proper nouns (Rule 9.9)

- Proper nouns used as appellative nouns (Rule 9.10)

- Language names and similar issues (Rule 9.11-9.12)

- Geographical names (Rule 9.13-9.15)

- Monetary units (Rule 9.16)

- Geological names (Rules 9.17-9.18)

- Derivations of proper names (Rules 9.19-9.24)

- Fading of proper names (Rule 9.25)

- Abbreviations (Rule 9.26)

\subsubsection{Kappie (Circumflex)}

The circumflex $(\wedge)$ is used in Afrikaans on vowels only, to indicate that the specific vowel sound should be stretched, e.g.: 
sê, hê; wîe; aikôna; brûe (Rule 10.1)

miljoenêr, sekondêr, skêr (Rule 10.2)

crêpe-de-chine, maître d'hôtel, tête-à-tête (Rule 10.3)

\subsubsection{Konsonante (Consonants)}

The use of consonants is not problematic in Afrikaans. Usage has usually to do with:

— the pronunciation of specific letters, e.g. robvleis [rop'fləis]/robbe [ro'bə] (Rule 11.1); hibried [hi'brit]/hibriede [hi'bri'də] (Rule 11.2);

- the usage of -de or -te in past participles (bedekte, geykte, gelapte, verlepte (Rule 11.6) or gestyfte/gestyfde; vereiste/vereisde (Rule 11.7) or gematigdheid/gematigtheid (Rule 11.8);

- the duplication of consonants between vowels, i.e. vodde; beddens; blokke; landskappe; sinusse (Rules 11.23-11.30).

\subsubsection{Koppelteken (Hyphen)}

The hyphen has several different usages in Afrikaans spelling conventions (cf. Rules 12.1-12.38), i.e. to assist with the readability of a word (see-eend); to join words in a specific combination to indicate a specific meaning (skriba-kassier); to use as a mark to indicate omission (Moeders- en Vadersdag; taal- en letterkundiges); to indicate a break in a word that cannot be written in full in a given line (ver-gadering).

\subsubsection{Meervoudsvorme (Plural forms)}

The plural forms of Afrikaans words (cf. Rules 13.1-13.30) are interdependent on issues such as vowels occurring in open and closed syllables, duplication of consonants, the use of the apostrophe, the use of diacritics, proper and appellative nouns, words of foreign heritage, job and title designations, abbreviations, and variants.

\subsubsection{Skryfwyse - los en vas (Styling of compounds - disjunctive and conjunctive)}

It is often difficult to determine whether Afrikaans words should be written disjunctively or conjunctively. Rules 14.1-14.53 address these issues.

\subsubsection{Verkleiningsvorme (Diminutives)}

Diminutive forms in Afrikaans end on the following: -ie, -jie, -etjie, -tjie, -kie 
and -pie. Rules 15.11-5.13 address the spelling conventions regarding diminutive forms in Afrikaans.

\subsubsection{Vokale (Vowels)}

Several factors influence the usage of vowels in the Afrikaans written format (cf. Rules 16.1-16.23), i.e. open or closed syllables, stress, origin of the word, origin of prefixes and suffixes in combination of the base word, sound environment, tradition, and the fact that the Afrikaans alphabet contains more vowels and diphthongs than the original Roman alphabet on which it was based.

\subsubsection{Wisseling en subkategorieë (Variants and subcategories)}

There are several spelling variation possibilities in Afrikaans, i.e. aalwyn/aalwee; Chinees/Sjinees; restaurant/restourant, etc. Rules 17.1-17.20 deal with variants and its subcategories.

\subsubsection{Woorde van vreemde herkoms (Words of foreign origin)}

Afrikaans, like any other language in contact with other living languages, is influenced by these languages. There are three basic principles governing the inclusion of foreign words in the Afrikaans vocabulary:

- Foreign words transliterated into Afrikaans according to the typical Afrikaans spelling conventions (e.g. atjar, barmitswa, kikoejoe (Rule 18.1));

- Foreign words retaining their original form (e.g. canyon, gentleman, mañana, oeuvre, pizza (Rule 18.2));

- Foreign words that are spelt partly according to the foreign spelling convention, partly according to the Afrikaans spelling conventions (e.g. Fanagalo/ Fanagalô/Fanakalo/Fanakalô; shongololo/sjongolôlo/songolôlo/songolôlo; kleza/klêza (cf. Rules 18.3-18.19).

\subsection{Word list}

Although the AWS is not a dictionary, it also contains a word list. The convention for adding words to the word list is to list words giving spelling problems, neologisms, complex words in order to illustrate word-forming processes and words whose existence is recognised in the Afrikaans vocabulary.

The Commission recently gave special attention to the word list by looking at every single word in it to test it against the spelling and orthographic rules. All words used as examples in the rules section were included in the word list. 
The rule numbers were added next to these example words to enable users to go back to the rule where more information is given on the specific spelling convention (cf. katôba of catawba (soort druiwe) 18.3). The Commission aims to compile an online version of the AWS where rule numbers next to words in the word list would refer the user with the aid of hyperlinks to the relevant rule.

The user receives assistance through the inclusion of typical or difficult Afrikaans words that are usually or easily misspelt (cf. fotoalbum; kat-en-muisspelery of kat-en-muisspelery; meisieskool; mes-en-vurk-laai of mes-en-vurklaai, -e; mans- en dameskoen, -e; netnoumaar; nieregeringsorganisasie, -s; ineens, nogeens, weereens 14.53; ook al).

The Commission included core terms from various subject areas to give recognition to these terms, e.g. stochasties of stogasties (wiskunde; statistiek). New coinages in Afrikaans are also given in the word list to recognise their existence, e.g. stratografie (wetenskap van aardlae).

Between 1959 and 1963 the SAAWK acted as adviser regarding the translation of the Koran into Afrikaans. A committee consisting of experts of the Middle Eastern languages and cultures and two members of the Taalkommissie of the SAAWK translated the document. Two copies of this translation are available at the SAAWK (cf. Kapp 2009: 382).

Between 1959 and 1963 the SAAWK acted as adviser regarding the translation of the Koran into Afrikaans. A committee consisting of experts of the Middle Eastern languages and cultures and two members of the Taalkommissie of the SAAWK translated the document. Two copies of this translation are available at the SAAWK (cf. Kapp 2009: 382). Since 2006 the current Commission documented the typical core Islamic words taken from the Koran for incorporation in the AWS (cf. Kapp 2009: 382). Several of these Islamic words were incorporated in the word list of the 2009 edition of the AWS. Typical terms relating to other religious denominations were also included.

\subsection{Back matter}

The back matter of the AWS consists of inter alia a list of abbreviations, a list of international geographical names, a transliteration table, etc. The planned online version will also include several other lists, e.g. the periodical table, a reference table on big and small numbers, a list of the monetary systems of the world with the relevant ISO codes, etc. These reference tables and lists are already completed and ready for inclusion.

\subsubsection{List of abbreviations}

A representative list of abbreviations and acronyms follows directly on the word list. The rules governing the way a word should be abbreviated in Afrikaans are supplied in section 3 of the rules' section. 


\subsubsection{List of international geographical names with derivations}

The South African geographical names are governed by the South African Geographical Names Council. There is, however, no official body governing the spelling and orthographic conventions of international place names in Afrikaans. The Commission therefore added a list with international geographical names with derivations (i.e. adjectives and inhabitants). These names were transliterated according to the Afrikaans spelling conventions.

\subsubsection{Transliteration table}

Language practitioners frequently encounter problems when Russian and Slavic names or their English versions have to be transliterated into Afrikaans. The transliteration table assists users with these problems.

The Commission also prepared transliteration tables for Arabic and Chinese. These tables will be part of the planned online version of the AWS.

\subsubsection{Colloquial Afrikaans}

The 2002 version of the AWS contained a list of typical colloquial Afrikaans words. These words were marked with an ${ }^{\circ}\left({ }^{\circ}=\right.$ Omgangsafrikaans $)$ to indicate that they are colloquial words and not part of the standard variety of the Afrikaans lexicon. Several users thought that the Commission permitted the usage of these colloquial words in the standard variety. The idea with their inclusion was, however, to assist authors when they have to spell the colloquial variety of Afrikaans. The Commission excluded the representative list of colloquial Afrikaans in the 2009 edition of the AWS, and this publication only contains six guidelines on how to spell colloquial Afrikaans, i.e.:

- Guidelines on spelling of words pronounced in a specific way, e.g. daai ${ }^{\circ} /$ darie $^{\circ}=$ daardie; hierie $^{\circ}=$ hierdie; kinners $^{\circ}=$ kinders (Guideline 1) .

- Guidelines on words borrowed from English, e.g. ghoef ${ }^{\circ}$ (swem), geghoef ${ }^{\circ}$ (geswem); moewies ${ }^{\circ}$, moewiese ${ }^{\circ}$ (tamaai, baie groot) (Guideline 2).

- Guidelines on typical English words frequently used in Afrikaans with Afrikaans pronunciation, e.g. brekfis ${ }^{\circ}$ (breakfast); orraait ${ }^{\circ}$ orrait $^{\circ}$ (all right) (Guideline 3).

- Guidelines on English words incorporated unchanged in Afrikaans, e.g. budget $^{\circ}$, gebudget ${ }^{\circ}$; coach $^{\circ}$, gecoach ${ }^{\circ}$; $\operatorname{sexy}^{\circ}$, sexiër ${ }^{\circ}$, $\operatorname{sexyste}^{\circ}$ (Guideline 4).

- Guidelines on English expressions used partially or fully in Afrikaans, e.g. boots en all $^{\circ} /$ boots en al $^{\circ}$; finish en klaar ${ }^{\circ}$; gepoeier en gepaint ${ }^{\circ}$ (Guideline 5).

- Guidelines on how to use English expressions in Afrikaans text, e.g. Ons 
was behoorlik "gecollar en getie " vir die okkasie (not *ge-"collar" en ge-"tie") (Guideline 6).

\subsubsection{Terminology list}

A terminology list explaining the meaning of terms used in the AWS was included as back matter. The list is arranged in alphabetical order and contains typical terms that might be problematic, i.e.

aanhefvorm: ' $n$ Aanhefvorm is die inleidende woord of woorde wat gerig word tot ' $n$ person of persone aan die begin van 'n brief, uitgeskrewe toespraak of dergelike teks, byvoorbeeld:

Geagte dr. Smit, Dames en Here, Heil die Leser, Liewe tannie Sarie

schwa: Die schwa is die vokaal [ə], byvoorbeeld in kamer, lig, peloton en basaar.

\subsubsection{Index}

An alphabetically arranged index and a useful quick reference system with running heads assist in the reference process, e.g.

graadwoorde 139-140, 560

leesbaarheidskoppelteken 75, 78-80, 92

\section{Related activities and future developments}

\subsection{Lara-TK}

All data accumulated by the Commission is in computerised format. The specific format was developed by the Centre for Text Technology (CText) of Northwest University, Potchefstroom campus. The computerised format is called "Lara-TK" and it contains all information regarding the word list, rules, etc. Lara-TK can be regarded as a blueprint of the AWS and future publications, whether hard copy or online versions, will be printed from this data base.

\subsection{TK Forum}

The members of the Taalkommissie of the SAAWK communicate on a daily basis on the TK Forum - this is an ideal way to solve spelling and orthography related problems encountered between the two formal meetings. Decisions taken are ratified at formal meetings. Present as well as previous members have access to the TK Forum. The members (a) address issues such as new words to be added to or deleted from the word list, and problematic words, and (b) share personal information and have quick access to any one or all of the members. The TK Forum was developed by TshwaneDJe Human Language 
Technology (cc) by request of Pharos Publishing House and it is for the exclusive use of the Taalkommissie.

\subsection{Facebook: Die Afrikaanse Taalkommissie}

The Taalkommissie keeps up to date with developments on the social networks and deals on a daily basis with language related matters on its Facebook page "Die Afrikaanse Taalkommissie". The members of the Taalkommissie take turns to address different problematic issues by writing a short paragraph on a specific issue at hand. Members of the public can then react on the relevant issue and receive more assistance. Members of the public could also use this Facebook page to directly consult the Taalkommissie on language related issues.

\section{4 e-AWS (electronic AWS)}

Although the AWS is already available on the Internet at www.woordelys.co.za (cf. De Bruyn 2013), the Taalkommissie plans to develop an electronic (e-book) and online version of the AWS, i.e. e-AWS (cf. SAAWK 2011: 78-82; SAAWK 2012: 9) for international access via the Internet. Users will be able to browse through the word list, abbreviation list and all other lists and will be able to refer to rules with the aid of hyperlinks. Interaction with users would be made available by supplying answers to frequently asked questions, and there would be a link to the Taalkommissie's Facebook page for direct consultation. The Taalkommissie would also be in a position to discuss suggestions for change and obtain comments and proposals from language users. Frequent updates would also be possible in an online version of the AWS.

\section{5 e-Grammatika van Afrikaans (e-Grammar for Afrikaans)}

The Taalkommissie formed a special subcommittee in close working relationship with various renowned scholars to compile an online grammar for Afrikaans, i.e. e-Grammatika van Afrikaans (cf. SAAWK 2011: 78-82; SAAWK 2012: 9). The $e$-Grammar would be descriptive and normative and would function as language portal. The scope would relate to morphology and syntax (morphosyntactic grammar) with a limited grammar (opposed to basic or extensive grammar) and it will focus on the written variety of standard Afrikaans. The e-Grammar could later incorporate phonology, school grammar and other varieties of Afrikaans.

The main aim with the e-Grammar is to develop Afrikaans linguistics and the target users are Afrikaans mother-tongue students.

The envisaged format is Wiki-based grammar for Afrikaans - a language portal. The language medium would be Afrikaans and it might later incorporate other languages. The time allocated for the development of this e-Grammar 
is five to ten years.

It is envisaged that the development of the e-Grammar would be financed by external bodies. The service to target users, however, would be free of charge.

The Taalkommissie would be the project leader and it would also supply technical assistance and hosting. The Taalkommissie would co-operate with various Afrikaans speaking scholars as well as with the Dutch language portal (Nederlandse "Taalportaal").

\section{Co-operation between Afrikaans, the other nine official African lan- guages and the Khoe and San languages}

During the consultative meeting organised by PanSALB in July 2004, it was decided to revise the spelling and orthographic rules of the nine official African languages, and the Khoe and San NLBs expressed an interest in the compiling of spelling and orthographic rules for these languages (cf. 2.2).

In 2004 the NLBs of the nine official African languages started with the revision of the spelling and orthographic rules of these languages. The first editions were published by PanSALB in 2008, but no revisions have been compiled since. The AWS could serve as example of what could be done for these African languages, as well as for the Khoe and San languages.

Co-operation between the various National Language Bodies could lead to an approved system of revision. The different orthographic and spelling rules should be streamlined. There could even be a process of harmonisation of spelling and orthographic rules that are similar in different African languages, Khoe and San, and Afrikaans (e.g. capitalisation, abbreviation processes, wordforming principles, etc.).

The history and development of the Afrikaans spelling and orthographic system could serve as an example of what could be done and what should be avoided. The AWS could be used as a basic format to address different spelling and orthographic issues. The Commission is prepared to co-operate with and assist the NLBs with the revision of their spelling and orthography rules and principles.

The revision of the spelling and orthographic rules of a dynamic and living language should concentrate on aspects such as:

- Description of the language (history of its development)

- Description of language change and modernisation

- Basic principles of the language

- A description of the grammar of the language

- The spelling of the distinctive features of aspiration, nasalisation and palatalisation, as well as the non-distinctive ones on vowel and consonant 
assimilation and elision (cf. Emenanjo 1998: 44-45)

- Tonal notation

- Pronunciation

- Word-forming principles for the creation of new words or terms (i.e. scientific and technological concepts)

- Word division

- Conjunctive and disjunctive writing

- Loan-words from living languages, transliteration from classical languages, intra-dialectal borrowings

- Punctuation issues

- Spelling of names (pronouns, place names (national and international), etc.)

- Usage and/or elevation of dialects, colloquialisms, slang and jargon (e.g. language usage in popular literature)

- Transcription procedures (i.e. writing of texts in dialects from praise songs, speeches, etc.)

- Principles for the creation of abbreviations and acronyms

- Terminology list (explanation of grammar terms and terms used in the publication on spelling and orthographic rules)

- Alphabetical word list representative of the vocabulary of the language (e.g. words with spelling problems, neologisms, complex words, acknowledgement of the existence of words)

\section{Conclusion}

Language is dynamic, it develops and changes and its spelling and orthography system should be revised and modernised at regular intervals. The spelling and orthography conventions of a language form an integral part of language renewal and therefore the spelling and orthographic rules of the standard variety of a language should be revised continuously to meet the needs and demands of language users.

The revision of the spelling and orthographic rules of the nine official African languages started in 2004 and the first revisions were published in 2008 by the National Language Bodies of PanSALB. The PanSALB Board requires revised versions to coincide with the five-year term of office of NLB members. Unfortunately there was since 2008 no indication from PanSALB's side that the NLBs of the official African languages will revise the spelling and orthographic 
rules of these languages. The Khoe and San NLBs also did not compile spelling and orthography rules for these languages. Only the Commission working on Afrikaans (i.e. Taalkommissie of the SAAWK cum TC: Standardisation, Afrikaans NLB, PanSALB) revises the Afrikaans spelling and orthographic rules on an ongoing basis. The process of the ongoing revision and publication of the Afrikaans spelling and orthographic rules as described in this article could serve as guide for the other official languages. Co-operation between the standardising bodies for Afrikaans and for the official nine African languages, and the Khoe and San languages could be beneficial to the further development of the official South African languages and the Khoe and San languages.

\section{Bibliography}

Abdulaziz, M.H. 1989. Development of Scientific and Technical Terminology with Special Reference to African Languages. Kiswahili 56: 32-49.

Alberts, M. 2005. National Language Bodies (NLBs) and Technical Committees (TCs). Paper read at the PanSALB Colloquium on National Language Bodies of 2005-11-11, PanSALB, Pretoria.

Alberts, M. 2006a. Standardisation, Modernisation and Harmonisation - Users' Perspectives. Paper read at the 11th International Afrilex Conference, 6-7 July 2006, Thohoyandou.

Alberts, M. 2006b. Standardisation, Modernisation and Harmonisation - A Sociolinguistic Perspective. Wang, Yuli, Yu Wang and Ye Tian (Eds.). 2006. TSTT' 2006 International Conference on Terminology, Standardization and Technology Transfer: Proceedings: 182-192. Beijing: Encyclopedia of China Publishing House.

De Bruyn, E. 2013. Taalkommissie kom voel polsslag van Afrikaans in Namibië. Republikein, 12 Maart 2013.

Departmental Northern Sotho Language Board. 19884. Northern Sotho Terminology and Orthography No. 4/Noord-Sotho terminologie en spelreëls No. 4/Sesotho sa Leboa mareo le mongwalo No. 4. Pretoria: Government Printer.

Department of Arts and Culture. 2011. Presentation to the Portfolio Committee: Arts and Culture on the South African Languages Bill 2011, 16 November 2011. Pretoria: Department of Arts and Culture.

Department of Sport, Recreation, Arts and Culture. 2005. Language Policy Framework of the Gauteng Provincial Government. Johannesburg: Gauteng Provincial Government.

Emenanjo, E.N. 1998. The Modernization of the Igbo Language and its Implications for Holistic Education. Prah, K.K. (Ed.). 1998: 43-52.

Finlayson, R. 2004. Consultative Meeting: Revision of the Spelling and Orthography Rules of the Official African Languages. Paper read at the PanSALB Consultative meeting held on 1-2 July 2004, Pretoria.

Government Gazette. 2012. Use of Official Languages Act 12 of 2012. Government Gazette, Vol. 568, No. 35742, 2 October 2012. Cape Town: The Presidency.

Government Gazette. 2013. SA Use of Official Languages Act - Proposed Regulations. Government Gazette 26, Notice 411 of 2013, No. 36392, April 2013: 56-67. Cape Town: National Parliament.

Kapp, P. 2009. Draer van 'n droom. Hermanus: Hemel \& See Boeke. 
McLachlan, J.D. 2001. AWS se 'gesag'. Van den Berg, L. (Ed.). 2001. Taalmanak: 1-3.

Msimang, C.T. 1998. The Nature and History of Harmonisation in South African Languages. Prah, K.K. (Ed.). 1998. Between Distinction and Extinction. The Harmonisation and Standardisation of African Languages: 165-174. Johannesburg: Witwatersrand University Press.

Pharos. 2009. Afrikaanse woordelys en spelreëls. Cape Town: Pharos.

PanSALB. 2008. Imithetho yokubhala nobhalomagama LwesiZulu. Pretoria: PanSALB.

PanSALB. 2008. Imithetho yokutlola nokupeleda isiNdebele. Pretoria: PanSALB.

PanSALB. 2008. Imitsetfo yekupela nelubhalomagama LweSiswati. Pretoria: PanSALB.

PanSALB. 2008. Melao ya mongwalo le mopeleto ya Sesotho sa Leboa. Pretoria: PanSALB.

PanSALB. 2008. Melawana ya mokwalo le mopeleto Setswana. Pretoria: PanSALB.

PanSALB. 2008. Melawana ya mopeleto le karohanyo ya mantswe mongolong wa Sesotho. Pretoria: PanSALB.

PanSALB. 2008. Milawu ya mapeleleto na matsalelo ya Xitsonga. Pretoria: PanSALB.

PanSALB. 2008. Milayo ya kupelet ele na kuńwalelle kwa Tshivenda. Pretoria: PanSALB.

Poulos, G. and L.J. Louwrens. 1994. A Linguistic Analysis of Northern Sotho. Hatfield, Pretoria: Via Afrika.

Poulos, G. and C.T. Msimang. 1998. A Linguistic Analysis of Zulu. Cape Town: Via Afrika.

Prah, K.K. 1993. Mother Tongue for Scientific and Technological Development in Africa. Bonn: German Foundation for International Development.

Prah, K.K. 1995a. African Languages for the Mass Education of Africans. Bonn: German Foundation for International Development.

Prah, K.K. 1995b. Mother Tongue for Scientific and Technological Development in Africa. Bonn: German Foundation for International Development Education, Science and Documentation Centre.

Ranger, T.O. 1989. Missionaries, Migrants and the Manyika: The Invention of Ethnicity in Zimbabwe. Vail, L. (Ed.). 1989. The Creation of Tribalism in Southern Africa: 118-151. London/ Berkeley/Los Angeles: James Currey.

SAAWK (Suid-Afrikaanse Akademie vir Wetenskap en Kuns). 2011. Notule 1 TK Maart 2011.1. 0GBVH.2011-04-12. Pretoria: SAAWK.

SAAWK (Suid-Afrikaanse Akademie vir Wetenskap en Kuns). 2012. Notule 1 TK Maart 2012.1. 5GBVH.2012-03-23. Pretoria: SAAWK.

\section{Internet Reference}

http: //www.en.wikipedia.org/wiki/orthography 